\title{
Habitat Distribution Of SMall MAMmal Communities in Grand Teton National PaRk
}

\author{
NANCY L. STANTON STEVEN W. BUSKIRK \\ DEPARTMENT OF ZOOLOGY AND PHYSIOLOGY \\ STEVEN L. MILLER $\bullet$ DEPARTMENT OF BOTANY \\ UNIVERSITY OF WYOMING • LARAMIE
}

\section{$\checkmark \quad$ INTRODUCTION}

One primary objective of this study was to survey small mammal communities in a burn chronosequence. During the summer of 1990 , small mammals were live-trapped in five burned sites and in adjacent unburned coniferous forests in and around Grand Teton National Park. In 1991, two burns (Huckleberry Mountain, 1988 fires) and adjacent unburned forests were trapped for the third consecutive year in June, July and August to continue to monitor post-burn small mammal population trends and species composition.

In addition, in 1991 rodents were live-trapped from seven vegetation types along an elevational gradient, and microhabitat measurements were made at successful and unsuccessful trap stations within each vegetation type. The purpose was to survey small mammal communities in common habitat types within the Park and to determine whether microhabitat features can be used to predict trap success for common rodent species.

\section{$\checkmark \quad$ METHODS}

In the summer of 1991, small mammals were trapped for four consecutive nights in June, July and August on four 1-ha grids at Huckleberry Mountain
(4430N-11041W UTM): a burn with an unburned control on both the east and the west sides of John D. Rockefeller Jr. Memorial Parkway.

In addition, in 1991 seven vegetation types were selected for additional small mammal sampling:

1) Pacific Creek Aspen (PCA)[4351N11031W UTM]; at an elevation of $2085 \mathrm{~m}$.

2) Snake River Riparian (SRR)[4347N11035W UTM]; elevation, $2036 \mathrm{~m}$.

3) Snake River Sagebrush (SRS)[4348N11035W UTM]; elevation, $2076 \mathrm{~m}$.

4) A wet meadow at Cathedral Group Pond (CGP) [4348N-11042W UTM]; elevation $2110 \mathrm{~m}$.

5) A riparian area along a medium gradient perennial stream Laurel Creek (LCR) [4347N11044W UTM]; elevation $2110 \mathrm{~m}$.

6) Whitebark pine at the headwaters of the South Fork of Cascade Canyon (CWP) [4344N11050W UTM]; elevation, $2950 \mathrm{~m}$.

7) Alpine meadows at Cascade (CAM) [4344N-11051 UTM]; elevation, $3048 \mathrm{~m}$.

Where possible, two parallel transects $10 \mathrm{~m}$ 
apart and consisting of 25 trap stations at $10 \mathrm{~m}$ intervals were established; but on the whitebark pine (Pinus albicaulus) stand, a rectangular grid was used instead. Due to logistics and the short growing season, the two high altitude sites (CWP and CAM) were only trapped in late July. The remaining sites were trapped for four consecutive days once a month for three months.

\section{SMALL MAMMALS}

A Sherman live trap baited with rolled oats and peanut butter was set at each station, opened between 1500 and 1700 , and checked the following morning during trapping periods. Traps were closed during the day. Captured animals were ear-tagged with unique metal fingerling tags; classified by species, sex, age class (juvenile or adult) and reproductive condition; weighed to the nearest $g$ and released. Fecal samples were collected from traps for fungal spore and parasite analyses.

Pitfall traps (335 ml plastic cups) were set at every fifth station, partially filled with propylene glycol and left open for three days to capture shrews and ground-dwelling arthropods. Small mammal population densities were calculated using Program Capture (Otis et al. 1978) and taxonomic nomenclature follows that of Jones et al. (1986).

\section{MICROHABITAT MEASUREMENTS}

Microhabitat measurements were taken at randomly selected stations within each grid along the elevational gradient: half were made at successful stations and half at unsuccessful stations. Microhabitat variables selected for measurement were those that emerged as most important in the discriminant function from the 1990 microhabitat data analyses. These variables included ground cover (Daubenmire Canopy Coverage Method), mesic status (distance to standing or running water or wetland), distance to and size of nearest tree and log, trap azimuth, canopy cover, height and number of species of herbaceous plants, and number of woody stems $/ \mathrm{m}^{2}$ (Deuser and Shugart 1978).

\section{$\checkmark \quad$ RESUlts}

In 4800 trap nights at the Huck sites, seven small mammal species were trapped in 1014 total captures (Table 1). The deer mouse (Peromyscus maniculatus), the southern red-backed vole (Clethrionomys gapperi) and the least chipmunk (Tamias minmus) were the most abundant species and the only species for which density estimates were possible.

Of the plots arranged elevationally, Laurel Creek had the highest number of species: the deer mouse, the southern red-backed vole, the western jumping mouse (Zapus princeps), the water vole (Microtus richardsoni), and the long-tailed vole ( $M$. longicaudus) (Table 2). The southern red-backed vole was the most abundant with densities increasing over the season from $33 /$ grid in June to $42 /$ grid in August.

Four species were trapped at Pacific Creek: the deer mouse, the least chipmunk, the montane vole, and the western jumping mouse. The density of the deer mouse ranged from 20/grid in June to 40/grid in August. The density of the montane vole reached a peak in August (54/grid) and the least chipmunk in July (18/grid).

Four species were trapped in the Snake River Riparian habitat and, in order of abundance, include the deer mouse, the western jumping mouse, the montane vole and the least chipmunk.

The Snake River sagebrush had low species richness: only the deer mouse was trapped during all three months, and one least chipmunk was trapped in August.

At Cathedral Group Pond and Cascade Alpine Meadow, only the deer mouse was abundant but one montane vole and one water vole were also trapped.

Finally, at Cascade Whitebark Pine only the deer mouse and the southern red-backed vole were trapped. Densities were relatively low at the two high elevation sites. Thus both species richness and density appear to have declined with increasing elevation.

\section{DISCUSSION}

Only the deer mouse was trapped at all sites. Peromyscus species are generally considered to be opportunistic both in habitat use and foraging 
Table 1. Density estimates, number/ha (Program CAPTURE, Otis 1978) [standard error] and total number of individuals trapped $(\mathrm{N})$ for the deer mouse (Peromyscus maniculatus), the southern red-backed vole (Clethrionomys gapperi) and the least chipmunk (Tamias minimus) in Huck west-facing burn (HWB) and control (HWC) and Huck east-facing burn (HEB) and control (HWC); (* not calculated, no captures or recaptures).

\begin{tabular}{|c|c|c|c|c|c|c|c|c|c|}
\hline & & June & & & July & & & August & \\
\hline & $\bar{x}$ & S.E. & $\mathbf{N}$ & $\bar{x}$ & S.E. & $\mathbf{N}$ & $\bar{x}$ & S.E. & $\mathbf{N}$ \\
\hline & & & & & manicul & & & & \\
\hline HWB & 18 & {$[0.02]$} & (18) & 14 & {$[0.01]$} & (14) & 39 & [1.25] & (38) \\
\hline HWC & 3 & {$[0.14]$} & (3) & 9 & [3.05] & (6) & 11 & {$[0.01]$} & (11) \\
\hline HEB & 20 & {$[0.01]$} & (20) & 47 & [3.09] & (42) & 90 & [3.95] & (81) \\
\hline HEC & 6 & {$[0.67]$} & (6) & $*$ & $*$ & (6) & 40 & [3.76] & (33) \\
\hline$\overline{\text { TOTAI }}$ & . & & (47) & & & $(68)$ & & & (163) \\
\hline & & & & & C. gappe & & & & \\
\hline HWB & $*$ & * & (5) & 13 & {$[0.58]$} & (13) & 17 & [0.02] & (17) \\
\hline HWC & 11 & {$[1.00]$} & (10) & 49 & [5.26] & (38) & 59 & [5.18] & (48) \\
\hline HEB & 2 & {$[0.00]$} & (2) & 9 & [5.02] & (5) & 18 & [2.94] & (14) \\
\hline HEC & 22 & [14.59] & (8) & 50 & [13.06] & (26) & 62 & {$[10.58]$} & (39) \\
\hline$\overline{\text { TOTAI }}$ & & & (25) & & & $(82)$ & & & (118) \\
\hline & & & & & minimus & & & & \\
\hline HWB & 9 & [1.95] & (7) & 23 & [16.43] & (8) & * & $*$ & (2) \\
\hline HWC & $*$ & * & (1) & $*$ & * & (1) & 1 & {$[0.00]$} & (1) \\
\hline HEB & 5 & {$[0.00]$} & (4) & 4 & [0.01] & (4) & * & $*$ & (0) \\
\hline HEC & $*$ & $*$ & (2) & $*$ & * & (0) & $*$ & $*$ & (0) \\
\hline$\overline{\text { TOTAI }}$ & & & (14) & & & (13) & & & \\
\hline
\end{tabular}


Table 2. Density estimates, number/.25ha, (Program CAPTURE) [standard error] and total number trapped (N) for seven elevational study sites in Grand Teton National Park; (* not calculated, no captures or recaptures).

\section{Laurel Creek Riparian}

\begin{tabular}{lccc} 
& \multicolumn{3}{c}{ June } \\
\cline { 2 - 3 } & $\overline{\mathrm{x}}$ & S.E. & $\mathrm{N}$ \\
P. maniculatus & 10 & {$[0.01]$} & $(10)$ \\
C. gapperi & 33 & {$[9.94]$} & $(18)$ \\
Z. princeps & 5 & {$[0.01]$} & $(5)$ \\
M. richardsoni & $*$ & $*$ & $(1)$ \\
M. longicaudus & $*$ & $*$ & $(0)$
\end{tabular}

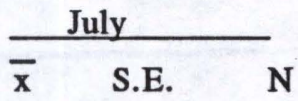

$10[1.04]$

$36[1.55]$

37 [12.54]

(1)

(0)
(9)

(34)

(18)

(6)

(0)

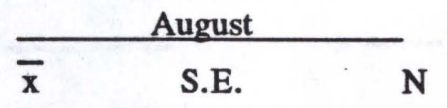

$27 \quad[1.84]$

$42 \quad[10.58](24)$

* *

*

TOTAL

(34)

(67)

Pacific Creek Aspen

P. maniculatus
T. minimus
M. montanus
Z. princeps

TOTAL

$\frac{\text { June }}{\overline{\mathrm{x}} \text { S.E. N }}$

20 [1.22]

10 [1.78]

* $*$

(19)

(8)

(0)

(0)

\section{(27)}

$\frac{\text { July }}{\overline{\mathrm{x}} \text { S.E. N }}$

38

18

[3.23]

[1.60]

$\begin{array}{ll}8 & {[0.01]}\end{array}$

(33)

(16)

(8)

(1)

$\frac{\text { August }}{\overline{\mathrm{x}} \text { S.E. N }}$

46 [2.77]

6 [2.53]

$54 \quad[42.45]$

3 [0.01]

5)

(57)

Snake River Riparian

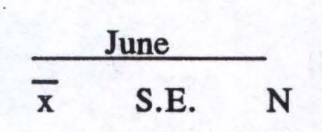

P. maniculatus

C. gapperi

T. minimus

M. montanus

Z. princeps
9 [2.30] (7)

*
$* \quad *$

* *

* *

$(7)$
$*$
$(0)$
$(0)$
$(1)$

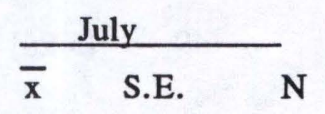

17 [0.84]

(0) *
(16)

*

* *

$4 \quad[0.01]$

(4)
(7)
$*$
$(0)$
$(0)$
$(1)$

(7)
$*$
$(0)$
$(0)$
$(1)$

(8)

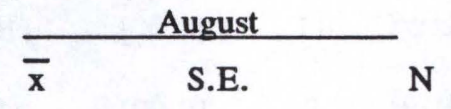

26

(0)

[1.94]

*

$*$

[2.12]

TOTAL

(21)

Snake River Sagebrush

P. maniculatus
T. minimus

\begin{tabular}{ccc}
\multicolumn{2}{c}{ June } \\
\hline $\bar{x}$ & S.E. & N \\
9 & {$[0.01]$} & $(9)$ \\
$*$ & $*$ & $(0)$
\end{tabular}

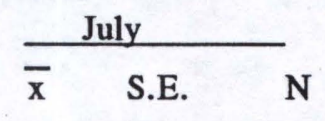

$\begin{array}{cc}22 & {[2.00]} \\ * & *\end{array}$

(20)

(0)

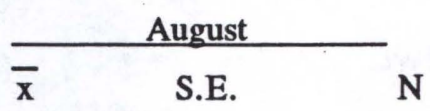

$\begin{array}{cc}9 & {[0.01]} \\ * & *\end{array}$

(9)

TOTAL

(9)

(20)

(10) 
Table 2. (con't)

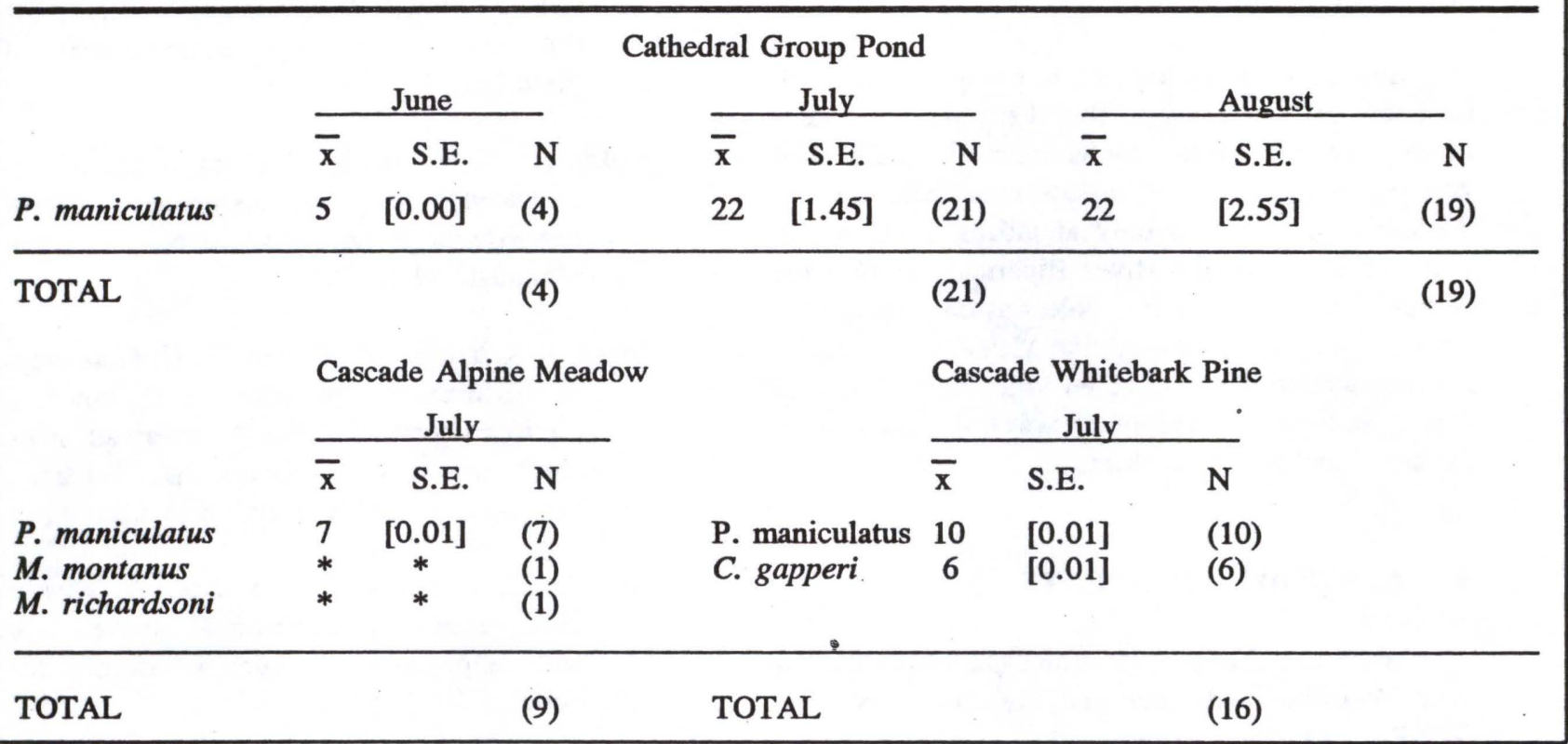

strategies (Holbrook 1978). For example, Williams (1959) examined the stomach contents of deer mice collected from Jackson Hole and found seeds (particularly conifer seeds), green vegetation, fungi and arthropods. Within burns, grass and herbaceous species probably provide an abundant seed resource and, with the absence of litter, foraging for seeds and insects may be more efficient.

At Huck, deer mice were more abundant in post-fire stands, and southern red-backed voles were more common in unburned stands. In 1990 we used discriminant analysis to test the hypothesis that microhabitat characteristics are predictive of trap success or failure. In unburned forests for southern red-backed voles, habitat variables were marginally capable of distinguishing between successful and unsuccessful trap sites. The habitat variables of greatest predictive value were diameter of nearest log (positively related), density of woody stems (negative) and distance to nearest tree (positive). These findings are consistent with the life history of Clethrionomys. Large-diameter logs result from tree fall, which leaves gaps in the canopy, and in the populations of live boles. Hence, the distance to trees increases in areas with large logs. Red-backed voles have been reported to associate closely with large diameter logs because of predator avoidance opportunities (Hayes and Cross 1987), and because of fungi that grow in and near coarse woody debris (Maser et al. 1978). Belk et al. (1988), in a principal components analysis of microhabitat use in aspen-Douglas fir forests in Utah, reported that the southern red-backed vole was found in areas with dense canopy cover, high log density and in dense woody vegetation.

The occurrence of deer mice in unburned forest could be predicted with high statistical significance using the 1990 microhabitat data. The discriminant function enabled classification that was $51 \%$ more accurate than would be the case with random assignment. Cover, height, and species richness of herbaceous vegetation were the most important habitat variables, all positively related to trap success. This is consistent with the herbivorous and seed diets of deer mice. The highly significant discriminant function can be interpreted to mean that trap success of deer mice in unburned forest was predictable by our habitat variables. Conversely, Belk et al. (1988) reported that the deer mouse in Douglas fir-aspen forests was associated with fallen logs and brush cover and negatively associated with cover and height of herbaceous vegetation.

The microhabitat data collected in 1991 from the seven sites along the elevational transect will be used for discriminant analysis to test the repeatability of 
the analyses of the 1990 microhabitat data, and to determine if the other species trapped separate out by microhabitat features.

Based upon last summer's trapping results, small mammal species (except for the ubiquitous deer mouse) can be separated by habitats: the red-backed vole was associated with mature coniferous forests; the montane vole was only abundant in aspen but occurred in the Snake River Riparian and Cascade Alpine Meadow; the water vole was only trapped at Laurel Creek and at the Alpine Meadow adjacent to running water; the long-tailed vole, only at Laurel Creek; and the least chipmunk was only abundant in the aspen and in the Huck burns.

\section{- ACKNOWLEDGEMENTS}

We thank David Spildie and David DuBay for their intensive field work and the Park Service at GTNP for logistical support.

\section{- Literature Cited}

Belk, M. C., H. D. Smith and J. Lawson. 1988. Use and partitioning of montane habitat by small mammals. J. Mammal. 69:688-695.

Dueser, R. D. and H. H. Shugart, Jr. 1978. Microhabitats in a forest-floor small mammal fauna. Ecol. 59:89-98.
Hayes, J. P., and S. P. Cross. 1987. Characteristics of logs used by western redbacked voles, (Clethrionomys californicus), and deer mice, (Peromyscus maniculatus). Can. Field Nat. 101:543-546.

Holbrook, S. J. 1978. Habitat relationships and coexistence of four sympatric species of Peromyscus in northwestern New Mexico. J. Mammal. 59:18-26.

Jones, J. K. Jr., D. C. Carter, H. H. Genoways, R. S. Hoffman, E. W. Rice and C. Jones. 1986. Revised checklist of North American mammals north of Mexico. Occasional Papers, The Museum, Texas Tech University, Lubbock.

Maser, C., J. M. Trappe, and R. A. Nussbaum. 1978. Fungal-small mammal interrelationships with emphasis on Oregon coniferous forests. Ecology 59:799-809.

Otis, D. L., K. P. Burnham, G. C. White and D. R. Anderson. 1978. Statistical inference from capture data on closed animal populations. Wildl. Monogr. 62:1-138

Williams, O. 1959. Food habits of the deer mouse. J. Mammal. 40:415-419. 